\title{
Low Doses of Interferon Alpha Result in More Effective Clinical Natural Killer Cell Activation
}

\author{
Bruce S. Edwards, James A. Merritt, Robert C. Fuhlbrigge, and Ernest C. Borden \\ Department of Human Oncology, University of Wisconsin Clinical Cancer Center, Madison, Wisconsin 53792
}

\begin{abstract}
To define critical parameters concerning interferon (IFN) effects upon natural killer (NK) cells in vivo, we gave cancer patients serial weekly intramuscular injections of purified lymphoblastoid IFN in six doses ranging from $10^{5}$ to $3 \times 10^{7} \mathrm{U}$. Dose sequences were determined by randomly allocating patients to one of six levels in a latin square ordering scheme. NK cell stimulation, a threefold peak increase above preinjection levels of cytolysis $(P=0.022)$, occurred in peripheral mononuclear cells (PMC) sampled $24 \mathrm{~h}$ postinjection, of $3 \times 10^{6} \mathrm{U}$, but was not detectable at any dose in PMC sampled $7 \mathrm{~d}$ postinjection. No blunting occurred in NK cell responsiveness to repeated injection of IFN dosages a second time at or several weeks after study completion. At IFN doses of $3 \times 10^{6}, 10^{7}$, and $3 \times 10^{7} \mathrm{U}$, a negative correlation existed between the amount of IFN injected and the average extent of NK cell activation ( $r$ $=-0.423, P<0.05)$. This contrasted with the progressively increasing response of $\mathrm{NK}$ cells to in vitro incubation with increasing concentration of up to $3,000 \mathrm{U} / \mathrm{ml}$ of IFN. Overnight culturing of PMC sampled before IFN injections resulted in a mean 1.9-fold increase in cytolytic activity $(P=0.0005)$ and a mean 53\% decrease in variance $(P=0.024)$ between serial preinjection NK cell activity determinations. Cell separation procedures may, therefore, have resulted in NK cell inactivation, from which overnight culturing permitted recovery. We found that maximal NK cell activation at a low IFN dose, decreasing NK cell responsiveness at higher doses, and the need to culture PMC to efficiently detect NK cell boosting may account for disparaties in reported effects of IFN on NK cell function.
\end{abstract}

\section{Introduction}

The natural killer (NK) ${ }^{1}$ cell system appears to be an immunological mechanism by which some tumor cells, virus-infected cells, and certain stem cells arising normally in bone marrow and thymus may be detected and eliminated in vivo $(1,2)$. Recent evidence suggests an additional immunoregulatory role of NK cells in termination of conventional antibody responses $(3,4)$ In in vitro systems, human NK cell cytolytic activity is

Address reprint requests to Dr. Edwards, Research Division, Lovelace Medical Center, 5400 Gibson, Southeast, Albuquerque, NM 87108.

Received for publication 13 April 1984 and in revised form 1 February 1985.

1. Abbreviations used in this paper: IFN, interferon; LU, lytic units; NK, natural killer; PMC, peripheral blood mononuclear cells; TCM, tissue culture medium.

J. Clin. Invest.

(c) The American Society for Clinical Investigation, Inc.

0021-9738/85/06/1908/06 \$1.00

Volume 75, June 1985, 1908-1913 consistently up-regulated in the presence of interferon (IFN). However, there is conflicting evidence regarding the NK cellactivating effects of clinically administered IFN. Many studies document significant IFN-induced increases in NK cell activity (5-11), whereas others report absence of an IFN effect $(9,12)$ or occasional IFN-mediated depression of cytolytic activity $(12,13)$.

Complexities of NK cell response regulation or kinetics in vivo may underlie these apparent discrepancies. For example, a single IFN injection may result in decreased NK cell activity several hours postinjection but lead to elevated levels of NK cell activity $24-48 \mathrm{~h}$ later $(5,7)$. On the other hand, NK cells may be initially activated, but become progressively less responsive to IFN after repeated daily injections over a course of several weeks $(7,8)$. In addition, there exists in individuals a normal degree of variation over time in basal unstimulated levels of NK cell activity that must be taken into account when assessing immunomodulatory effects of an IFN regimen $(11,12,14)$.

Although a substantial body of evidence exists that NK cells inhibit tumor growth in vivo in animals, evidence that they are involved in tumor immunity in humans is thus far indirect and somewhat less consistent $(1,2)$. The use of biological response-modifying drugs such as IFN in controlled clinical trials under conditions in which NK cell responses are known to be optimally modulated may provide a means of clearly defining the importance of NK cells in control of human tumor growth. This study was, therefore, undertaken to define an IFN dose that would result in optimal NK cell activation. Cancer patients were given a series of sequential injections of different IFN dosages, the specific order of which was varied from one patient to the next according to a latin square experimental design. We assessed the effects of culturing mononuclear cells in vitro overnight before performance of NK cell assays with respect to variance in serial preinjection NK cell activity determinations and detectability of NK cell immunomodulation resulting from IFN.

\section{Methods}

IFN. Human lymphoblastoid IFN was provided by the Burroughs Wellcome \& Co., Greenville, NC, through the Biological Response Modifiers Program of the National Cancer Institute. This preparation constituted $75-85 \%$ IFN protein representing eight distinct species of IFN- $\alpha$ as determined by polyacrylamide gel electrophoresis (15). Specific antiviral activity was $1.0-1.7 \times 10^{8} \mathrm{U} / \mathrm{mg}$ protein. All antiviral units were expressed by comparison with the international standard for leukocyte IFN (G023-901-527).

Study design. Seven patients with metastatic malignancy (two, renal carcinoma; one each, breast; ovarian; head and neck carcinoma; malignant hemangiopericytoma; and non-Hodgkin's lymphoma, stage IV) were given intramuscular injections of $10^{5}, 3 \times 10^{5}, 10^{6}, 3 \times 10^{6}$, $10^{7}$, and $3 \times 10^{7} \mathrm{U}$ of lymphoblastoid IFN. Sequential injections were separated by a washout period of at least $7 \mathrm{~d}$. Six different predetermined 
dose sequences were randomly assigned to patients. The designation of sequences was based upon a $6 \times 6$ latin square design (16), such that each dose was preceded and followed by each of the other doses at least once (Table I). In this manner, any specified dose was administered as the first injection in one patient, the second injection in another patient, the third injection in yet another patient, and so on. Thus, at each weekly injection during the first 6 wk of the study, six patients received six different doses. A seventh patient received the same sequence of injections as one of the others. In the 7th week of the study, each patient was given the same IFN dose received the previous week. Four patients received one additional injection of $10^{6}$ $\mathrm{U}$ at a time point $3 \mathrm{wk}$ or more after completion of the 7-wk study.

Detailed clinical findings in this study are to be published separately (Edwards, B. S., J. A. Merritt, R. C. Fuhlbrigge, and E. C. Borden, manuscript in preparation).

Cell preparations. As previously described (11), peripheral blood mononuclear cells (PMC) were obtained from patients just before and $24 \mathrm{~h}$ after each IFN injection, separated on Ficoll-Hypaque gradients, and washed three times to remove IFN that might have been carried over in serum. PMC were tested for NK cell activity immediately thereafter. In addition, 5-10 $\times 10^{6} \mathrm{PMC}$ were added to $25 \mathrm{~cm}^{2}$ upright plastic tissue culture flasks (Corning Glass Works, Corning Science Products, Corning, NY) as a suspension in $2 \mathrm{ml}$ of tissue culture medium (TCM): RPMI 1640 (Gibco Laboratories, Grand Island, NY) containing $24 \mathrm{mM}$ Hepes buffer, $0.01 \mathrm{mg} / \mathrm{ml}$ gentamicin, and $10 \%$ fetal calf serum (HyClone Laboratories, Sterile Systems, Inc., Logan, UT). After $18-20 \mathrm{~h}$ incubation at $37^{\circ} \mathrm{C}$ under $5 \% \mathrm{CO}_{2}$, these PMC were washed two times with TCM and tested for NK cell activity. To assess in vitro IFN effects, IFN was added at various concentrations to PMC suspensions for the duration of the 18-20-h incubation.

The single cell complement fixation method of Perussia et al. (17) was used to determine the phenotype of active NK cells (i.e., lymphocytes bound to dead K562 target cells) resident in overnight-precultured cell preparations. We determined them to be $\mathrm{OKT}^{-}, 40-50 \% \mathrm{OKT}^{+}$, $60-80 \% \mathrm{OKM}^{+}$, and $70-80 \%$ OKT $11^{+}$. The NK cell-specific monoclonal antibody B73.1 plus complement has been reported to completely eliminate NK cell activity in both freshly prepared cells and cells incubated overnight with IFN- $\alpha(18)$. Thus, by these criteria, overnightcultured NK cells were phenotypically similar to fresh NK cells.

K562 target cells were routinely screened for mycoplasma contamination by the Wisconsin State Public Health Laboratories, Madison, WI, using the method of Hayflick (19) and were consistently negative.

Chromium-release assay. Standard ${ }^{51} \mathrm{Cr}$ release assays were performed as previously described (20) in a total volume of $200 \mu \mathrm{l} /$ well using 96-well round bottom microplates (Linbro Chemical Co., Hamden, CT). Briefly, K562 target cells were labeled for $2 \mathrm{~h}$ at $37^{\circ} \mathrm{C}$ with 100 $200 \mu \mathrm{Ci} \mathrm{Na}{ }^{51} \mathrm{CrO}_{4}$ (New England Nuclear, Boston, MA), washed twice, and $2 \times 10^{3}$ cells suspended in TCM were added to each well. Graded concentrations of PMC were added to wells in quadruplicate and incubated $6 \mathrm{~h}$ at $37^{\circ} \mathrm{C}$ in $5 \% \mathrm{CO}_{2}$, after which supernatants were harvested, using a Titertek supernatant collection system (Flow Laboratories, Inc., Flow General Inc., McLean, VA), and counted in a gamma counter. Percent specific ${ }^{51} \mathrm{Cr}$ release mediated by NK cells was calculated as follows: (cpm test well release $-S) /(M-S) \times 100$, in which $S$ is counts per minute spontaneously released and $M$ is maximum counts per minute released by target cells incubated with detergent. Results at six different effector/target ratios were routinely assessed (3.125:1, 6.25:1, 12.5:1, 25:1, 50:1, and 100:1).

A modification of the exponential fit equation of Pross et al. (21), which was used to calculate lytic units (LU), is as follows: cpm test well release $=M\left(1-e^{-k(E / T)}\right)+S$, in which $E$ is the number of effector cells, $T$ the number of target cells (2,000/well), and $M$ and $S$ are as above. The cytotoxicity constant $k$ describes the relationship between the number of effector cells present and the number of target cells lysed and is proportionally related to the number of LU present in an effector cell preparation. One LU was defined as the number of lymphocytes required to result in $30 \%$ specific ${ }^{51} \mathrm{Cr}$ release. Consistent with findings of others using this type of curve-fitting methodology $(21,22)$, the ratio of $L U$ values calculated for any two fitted cytotoxicity curves was the same regardless of the LU definition.

Statistical analysis. LU determinations were approximately lognormal in distribution. Therefore, logarithms were taken of $L U$ values before performance of statistical evaluations. Paired comparisons were performed using a two-tailed paired $t$ test. For correlation analysis of IFN dosage effects, NK cell responses to IFN treatment were quantitated as the difference: $\log _{10} \mathrm{LU}$ in cells sampled $24 \mathrm{~h}$ postinjection of IFN minus $\log _{10} \mathrm{LU}$ in cells sampled just before injection. Correlation determinations were made using Spearman's product-moment correlation coefficient.

\section{Results}

Dose-response relationship. Patients received six different doses of IFN in an order predetermined by the level of a latin square dosing regimen to which each patient was randomized (Table I). As in a previous study (11), mononuclear cells were sampled just before and $24 \mathrm{~h}$ after each injection, washed extensively to remove any IFN that might have been present in the patient's serum, cultured overnight at $37^{\circ} \mathrm{C}$, and assayed the following day for the presence of NK cell activity. Peak NK cell activation, corresponding to a mean threefold increase above preinjection levels of NK cell activity, resulted from injection of $3 \times 10^{6} \mathrm{U}(P=0.022$, Table II). A reciprocal dose-response relationship occurred at higher dosages, such

Table I. Sequence of IFN Dosages Given to Individual Patients

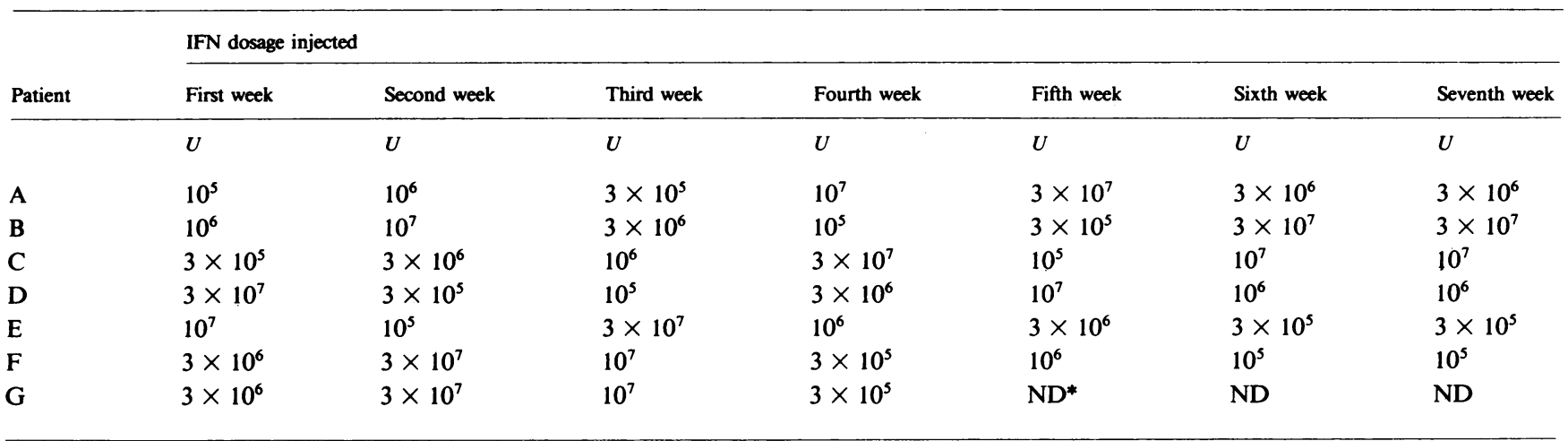

* ND, not done. 
Table II. Dose-Response Relationship of NK Cell Activation by Intramuscular IFN Injections

\begin{tabular}{|c|c|c|c|c|c|c|c|}
\hline \multirow[b]{2}{*}{ Patient } & \multirow[b]{2}{*}{ Sample time } & \multicolumn{6}{|c|}{ NK cell activity (LU/107 cells) } \\
\hline & & $10^{5 *}$ & $3 \times 10^{5 *}$ & $10^{6 *}$ & $3 \times 10^{6 *}$ & $10^{7 *}$ & $3 \times 10^{7 *}$ \\
\hline & & $U$ & $U$ & $U$ & $U$ & $U$ & $U$ \\
\hline \multirow[t]{2}{*}{ A } & Pre-IFN & 18.3 & 29.6 & $18.5(21.8)$ & $22.9(36.1)$ & 23.6 & 29.9 \\
\hline & 24 h Post-IFN & 38.8 & 13.3 & $78.2(34.4)$ & $176.4(113.6)$ & 23.3 & 27.9 \\
\hline \multirow[t]{2}{*}{ B } & Pre-IFN & 68.1 & 170.3 & 54.4 & 24.2 & 73.2 & $67.5(61.5)$ \\
\hline & 24 h Post-IFN & 26.5 & 61.8 & 61.7 & 65.1 & 53.3 & $105.1(33.9)$ \\
\hline \multirow[t]{2}{*}{$\mathbf{C}$} & Pre-IFN & 145.8 & 92.6 & $242.2(243.1)$ & 364.6 & $178.1(116.7)$ & 143.2 \\
\hline & 24 h Post-IFN & 286.0 & 154.4 & $142.8(722.6)$ & 284.0 & $117.2(133.3)$ & 163.3 \\
\hline \multirow[t]{2}{*}{ D } & Pre-IFN & 74.6 & 78.3 & $63.2(60.6)$ & 78.6 & 31.5 & 54.0 \\
\hline & 24 h Post-IFN & 117.9 & 42.8 & $161.8(122.4)$ & 56.8 & 433.3 & 7.5 \\
\hline \multirow[t]{2}{*}{$\mathbf{E}$} & Pre-IFN & 103.3 & $96.9(66.7)$ & $219.9(117.8)$ & 76.9 & 92.5 & 74.6 \\
\hline & 24 h Post-IFN & 114.6 & $248.8(103.3)$ & 94.7 (337.8) & 479.4 & 98.5 & 190.8 \\
\hline \multirow[t]{2}{*}{$\mathbf{F}$} & Pre-IFN & $32.4(31.1) \ddagger$ & 17.6 & $36.3(20.4)$ & 16.4 & 27.4 & 115.0 \\
\hline & 24 h Post-IFN & $53.6(18.3)$ & 32.9 & $15.7(98.8)$ & 32.2 & 42.2 & 107.9 \\
\hline \multirow[t]{2}{*}{ G } & Pre-IFN & ND§ & 24.0 & ND & 17.2 & 23.1 & 18.2 \\
\hline & 24 h Post-IFN & ND & 28.9 & ND & 229.7 & 71.5 & 63.3 \\
\hline Geometric & Pre-IFN & 54.5 & 56.2 & 65.5 & 43.4 & 53.5 & 59.2 \\
\hline means & 24 h Post-IFN & 63.0 & 58.2 & 105.0 & 128.5 & 84.1 & 59.6 \\
\hline
\end{tabular}

* IFN dose. $\ddagger$ Numbers in parentheses represent cytolysis by NK cells sampled before and after IFN injections given during week 7 or 3 or more weeks later. $\S \mathrm{ND}$, not done.

that a mean 1.6-fold increase resulted from $10^{7} \mathrm{U}$ and a mean increase of only 1.01-fold from $3 \times 10^{7} \mathrm{U}$ (Fig. 1). When responses obtained in all patients to injection of $3 \times 10^{6}, 10^{7}$, and $3 \times 10^{7} \mathrm{U}$ were examined together, there existed a significant negative correlation between the IFN dosage administered and the extent of change in NK cell activity that resulted ( $r$ $=-0.423, P<0.05$ ). The greatest relative increase above preinjection levels of NK cell activity resulted from $10^{6} \mathrm{U}$ in two patients (C and F), $3 \times 10^{6} \mathrm{U}$ in four patients (A, B, E, and $\mathrm{G})$, and $10^{7} \mathrm{U}$ in one patient (D).

Analysis of carry-over effects of multiple IFN injections. Multiple daily IFN injections given over a course of several weeks result in a progressive blunting of the capacity of NK cells to be activated by $\operatorname{IFN}(7,8)$. The latin square design for administering IFN. dosages was specifically used to minimize effects of such blunting, if it occurred, upon the analysis of IFN dosage effects. However, it was of interest to determine if impairment in stimulation resulted from multiple weekly IFN

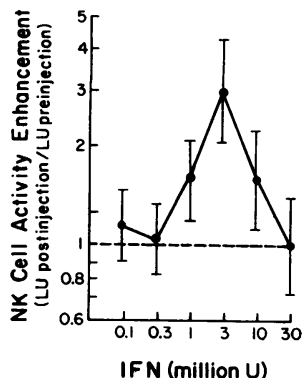

Figure 1. Dose response of acute stimulatory effects of intramuscular injection of IFN- $\alpha$ upon NK cell activity. NK cell activation was quantified as the ratio of LU in PMC sampled $24 \mathrm{~h}$ postinjection to $L U$ in cells sampled just before each injection $( \pm \mathrm{SEM})$. One LU was defined as the number of effector cells required to result in lysis of $30 \%$ of $\mathrm{K} 562$ target cells. injections. Six patients (A-F) received the same dose in week 7 as in week 6. Four patients (A, C, E, and F) received one additional injection of $10^{6} \mathrm{U} 3$ wk or more after completion of the 7-wk study. NK cell activity increased from a mean of 69.6 to $97.5 \mathrm{LU} / 10^{7}$ cells after the first injection and from 58.7 to $99.8 \mathrm{LU} / 10^{7}$ cells after the second injection. In 6 of these 10 paired equal dose-response assessments, NK cell activity resulting from the second injection was lower than that resulting from the first injection, whereas the opposite relationship occurred in the remaining 4 comparisons (Table II). Therefore, no general trend toward diminished NK cell responsiveness to repeated weekly IFN injections occurred within the time period examined.

A degree of variability existed in preinjection NK cell activity from one week to the next in a number of patients. To determine if this variability reflected carry-over effects from previous IFN injections, comparisons were made between levels of NK cell activity present just before injection of a specified dosage and $7 \mathrm{~d}$ later just before the next injection. Consistent with results of a similar analysis made in a separate study (23), no extended activating effects of single IFN injections at any of the tested dosages were detectable by this method of analysis (Table III). Variability in preinjection NK cell activity may, therefore, have reflected normal day to day differences in basal cytolytic potential (11). It was noteworthy that weekly preinjection levels of NK cell activity varied to a remarkably small extent in two patients (A and $G$ ) in both of whom 3 $\times 10^{6} \mathrm{U}$ resulted in maximal boosting (Table II).

Effects of culturing cells upon the analysis of NK cell potentiation. To determine what effect, if any, overnight culture 
Table III. Evaluation of Residual IFN Effects at the End of the Washout Period

\begin{tabular}{lllllll}
\hline & \multicolumn{2}{l}{ NK cell activity $\left(\mathrm{LU} / 10^{7}\right.$ cells) } & & & & \\
\cline { 2 - 7 } Sample time & $10^{5} \ddagger$ & $3 \times 10^{5} \ddagger$ & $10^{6} \ddagger$ & $3 \times 10^{6} \ddagger$ & $10^{7} \ddagger$ & $3 \times 10^{7} \ddagger$ \\
\hline Pre-IFN & 59.7 & 63.0 & 70.5 & 44.5 & 47.8 & 58.8 \\
7d Post-IFN & 68.4 & 68.7 & 60.0 & 62.7 & 42.1 & 65.4 \\
\hline
\end{tabular}

* Geometric means over all patients tested at the indicated dosage. $¥$ IFN dose.

of mononuclear cells in vitro might have had in the analysis of NK cell potentiation, cells were also tested for the presence of cytolytic activity just after their separation on Ficoll-Hypaque gradients. NK cell activity in cells sampled before IFN injections was higher when it was assayed after culture of the cells overnight at $37^{\circ} \mathrm{C}$ as compared with when it was assayed just after cell separation (Table IV). The average increase in cytolysis was $\sim 1$.9-fold $(P=0.0005)$ and ranged between 1.4 and 2.6-fold in individual patients. The estimated variance of serial weekly preinjection NK cell activity determinations decreased in six of the seven patients as a result of culturing cells before assay (Table IV). The mean decrease in variance was $52.5 \%(P=0.024)$.

When effects of IFN injections were assessed using freshly prepared cells, results sharply contrasted with those obtained in parallel experiments using overnight precultured cells. No mean augmenting effects of IFN treatment upon NK cell activity were detectable at any IFN doses (Table V). Thus, overnight culturing of mononuclear cells was of critical importance in NK cell expression of IFN-mediated effects.

In vitro dose-response relationship. When incubated in vitro with mononuclear cells, the same IFN preparation used in treatment of patients resulted in NK cell activation that approached a plateau of $300 \mathrm{U}$ of IFN (Fig. 2). A 10-fold greater IFN concentration, in excess of serum IFN concentrations measured $8 \mathrm{~h}$ after injections of $3 \times 10^{6} \mathrm{U}$ (range $=270$
$1,000 \mathrm{U} / \mathrm{ml}$; Merritt, J. A., L. A. Ball, K. M. Sielaff, D. M. Meltzer, and E. C. Borden, manuscript in preparation), resulted in a slight further increment in cytolytic activity. This asymptotic increase in NK cell activity that resulted from in vitro treatment with high concentrations of IFN was in distinct contrast to the reciprocal dose response of NK cells to injection of high doses.

\section{Discussion}

Maximal stimulation of NK cell activity, approximating an average threefold increase above preinjection background levels of cytolytic activity, resulted from single intramuscular injections of $3 \times 10^{6} \mathrm{U}$ of IFN. At a 10-fold greater dosage, although boosting appeared to occur in some individuals (patients $\mathrm{E}$ and $\mathrm{G}$ in Table II), the mean IFN effect over all patients was nil. A latin square dose sequencing schedule was used to minimize the probability that differences in NK cell activation could be attributed to experimental variables unrelated to IFN dosage differences. Moreover, retrospective analysis revealed no evidence for interinjection carry-over effects, the putative existence of which stimulated our use of the latin square dosing approach. NK cell activation measurable $24 \mathrm{~h}$ after injection of $3 \times 10^{6} \mathrm{U}$ was no longer detectable $7 \mathrm{~d}$ postinjection (Table III). No detectable "exhaustion" of NK cell responsiveness to IFN occurred in patients as a result of their receiving multiple weekly IFN injections over the 7-wk

Table IV. Effects on Serial Preinjection NK Cell Activity Determinations of Culturing Mononuclear Cells

\begin{tabular}{|c|c|c|c|c|c|c|}
\hline \multirow[b]{2}{*}{ Patient } & \multirow[b]{2}{*}{$n$} & \multicolumn{2}{|c|}{ NK cell activity $\left(\mathrm{LU} / 10^{7}\right.$ cells) ${ }^{*}$} & \multicolumn{3}{|c|}{ Varianceł } \\
\hline & & Fresh & Cultured & Fresh & Cultured & Decrease \\
\hline & & & & & & $\%$ \\
\hline A & 7 & 12.4 & 24.8 & 0.0853 & 0.0123 & 85.5 \\
\hline B & 7 & 25.3 & 64.8 & 0.0445 & 0.0615 & -38.1 \\
\hline C & 7 & 107.2 & 166.3 & 0.1211 & 0.0400 & 67.0 \\
\hline $\mathrm{D}$ & 7 & 35.0 & 60.5 & 0.0870 & 0.0196 & 77.5 \\
\hline $\mathrm{E}$ & 7 & 61.5 & 96.6 & 0.0610 & 0.0296 & 51.5 \\
\hline $\mathbf{F}$ & 7 & 22.9 & 31.8 & 0.1069 & 0.0778 & 27.2 \\
\hline G & 4 & 8.1 & 20.4 & 0.1624 & 0.0053 & 96.7 \\
\hline Means & & 28.0 & $\begin{array}{l}51.8 \\
(P=0.0005) \S\end{array}$ & & & $\begin{array}{l}52.5 \\
(P=0.024)^{\prime \prime}\end{array}$ \\
\hline
\end{tabular}

* Mononuclear cells were sampled just before each IFN injection and assayed in ${ }^{51} \mathrm{Cr}$ release assays either immediately after cell separation (fresh) or after overnight preincubation at $37^{\circ} \mathrm{C}$ (cultured). Represented are geometric means for all preinjection NK cell activity determinations made in each patient. $¥$ The variance between serial preinjection NK cell activity determinations was calculated using $\log _{10}$-transformed LU values: $\%$ decrease $=[1-($ variance in cultured cells/variance in fresh cells $)] \times 100 . \S P$ value pertains to comparison of LU in cultured cells with LU in fresh cells based upon paired two-tailed $t$ test analysis of $\log _{10}$-transformed LU data. " $P$ value pertains to the probability that the null hypothesis, $\%$ decrease $=0$, is true. 
Table V. Lack of Detectable IFN Activation in Mononuclear Cells Tested Just After Separation

\begin{tabular}{|c|c|c|c|c|c|c|c|}
\hline \multirow[b]{2}{*}{ Patient } & \multirow[b]{2}{*}{ Sample time } & \multicolumn{6}{|c|}{ NK cell activity (LU/10 cells) } \\
\hline & & $10^{5 *}$ & $3 \times 10^{5 *}$ & $10^{6 *}$ & $3 \times 10^{6 *}$ & $10^{7 *}$ & $3 \times 10^{7 *}$ \\
\hline & & $U$ & $U$ & $U$ & $U$ & $U$ & $U$ \\
\hline \multirow[t]{2}{*}{ A } & Pre-IFN & 30.6 & 12.4 & 9.0 & $29.9(10.7)$ & 5.0 & 8.2 \\
\hline & 24 h Post-IFN & 20.1 & 10.8 & 13.3 & $20.4(34.2)$ & 12.6 & 24.0 \\
\hline \multirow[t]{2}{*}{ B } & Pre-IFN & 15.4 & 19.2 & 34.3 & 44.0 & 17.9 & $17.1(48.6)$ \\
\hline & 24 h Post-IFN & 16.0 & 29.0 & 34.4 & 27.4 & 14.0 & $25.7(19.3)$ \\
\hline \multirow[t]{2}{*}{ C } & Pre-IFN & 55.0 & 76.7 & 166.9 & 165.7 & $241.1(205.8)$ & 27.8 \\
\hline & 24 h Post-IFN & 49.4 & 42.2 & 132.7 & 32.2 & $54.6(23.1)$ & 71.8 \\
\hline \multirow[t]{2}{*}{ D } & Pre-IFN & 19.2 & 31.0 & $40.3(104.0)$ & 36.9 & 54.0 & 12.9 \\
\hline & 24 h Post-IFN & 15.0 & 12.4 & $27.5(40.4)$ & 57.5 & 21.1 & 10.6 \\
\hline \multirow[t]{2}{*}{$\mathbf{E}$} & Pre-IFN & 88.1 & $40.6(115.3)$ & 59.0 & 119.3 & 27.6 & 41.5 \\
\hline & 24 h Post-IFN & 84.7 & $51.7(57.9)$ & 61.9 & 26.7 & 33.8 & 61.5 \\
\hline \multirow[t]{2}{*}{$\mathbf{F}$} & Pre-IFN & $30.8(18.3) \ddagger$ & 33.9 & 49.3 & 5.4 & 16.1 & 39.6 \\
\hline & 24 h Post-IFN & $15.0(64.2)$ & 34.0 & 42.6 & 15.7 & 15.3 & 12.6 \\
\hline \multirow[t]{2}{*}{ G } & Pre-IFN & ND§ & 24.4 & ND & 3.3 & 12.1 & 4.3 \\
\hline & 24 h Post-IFN & ND & 32.8 & ND & 24.6 & 77.9 & 18.9 \\
\hline Geometric & Pre-IFN & 30.5 & 34.9 & 48.4 & 25.6 & 32.7 & 19.1 \\
\hline means & 24 h Post-IFN & 29.5 & 29.3 & 40.5 & 27.9 & 25.7 & 24.5 \\
\hline
\end{tabular}

* IFN dose. $¥$ Numbers in parentheses represent cytolysis by NK cells sampled before and after IFN injections given during week 7 . § ND, not done.

period encompassed by the study (Table II). Thus, the progressive decrease in average NK cell boosting appeared to be primarily attributable to a reciprocal dose response at IFN dosages exceeding $3 \times 10^{6} \mathrm{U}$. This inverse dose relationship confirmed and extended results obtained in a separate clinical study involving two purified recombinant species of IFN- $\alpha$, in which only two doses were comparatively evaluated (23).

In a previous study a significant correlation existed between activation of a patient's NK cells by an optimal IFN concentration in vitro and activation measurable in NK cells from the same patient sampled $24 \mathrm{~h}$ postinjection of relatively low IFN dosages (11). A clear discrepancy between results of in vitro and in vivo IFN treatment occurred at higher IFN dosages in the present study. Thus, NK cell responsiveness to IFN in vitro may only be predictive of NK cell-activating effects of low IFN dosages in vivo. The mechanism of the suppressed response to higher doses of IFN in vivo remains to be determined.

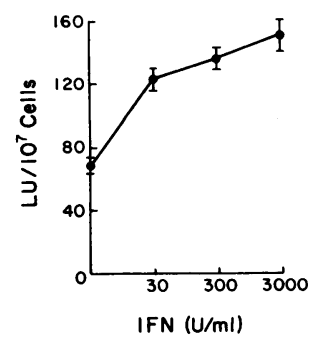

Figure 2. Dose response of NK cells to in vitro lymphoblastoid IFN treatment. PMC from a healthy individual were incubated $18 \mathrm{~h}$ at $37^{\circ} \mathrm{C}$ with indicated concentrations of IFN, washed, and tested for NK cell activity in a $2-h^{51} \mathrm{Cr}$ release assay. Represented are LU/10 ${ }^{7}$ cells \pm SEM, as determined by exponential curve fitting of ${ }^{51} \mathrm{Cr}$ release data from six different effector/target ratios (see Methods). Similar results were obtained in two additional experiments.
Using mononuclear cells precultured overnight before assay in this and previous studies $(11,23)$, enhancing effects upon NK cell cytolytic activity occurred which could only be attributed to prior exposure of NK cells to IFN in vivo. However, NK cell activation was undetectable when the period of cell culture intervening between cell separation and performance of cytotoxicity assays was omitted (Table V). NK cells, exposed to IFN in vivo, may possibly fail to acquire or express an activated state until removed from the in vivo environment. An alternative explanation might be that cell separation procedures result in a degree of NK cell inactivation from which overnight culturing permits recovery. In accord with this interpretation were our findings that the increase in NK cell activity that resulted from overnight culture was accompanied by a significant reduction in interassay variance between serial weekly preinjection NK cell activity determinations (Table IV). Also favoring this interpretation were previous findings that Ficoll-Hypaque enhanced Fc receptor-dependent binding of serum IgG to cells during separation (24) and that such binding transiently inhibited NK cell activity (25). This effect of cell culture may account for some of the discrepancies in results of in vivo IFN treatment reported by other laboratories (12).

The relationship between NK cell activation and antitumor response in humans remains to be determined. It may be relevant to our findings that Sherwin et al. (26) recently reported that $5 \times 10^{7} \mathrm{U}$ doses of recombinant IFN- $\alpha$ given to breast cancer patients in a phase II clinical trial resulted in no significant antitumor effects. In contrast, in a previous multiinstitutional trial in which breast cancer patients were given 3 
$\times 10^{6} \mathrm{U}$ doses of native Cantell IFN- $\alpha$ (Finnish National Red Cross), significant tumor responses occurred in $20 \%$ of the patients (8). Although the IFN dose was only one parameter by which these two clinical trials differed, the difference in dosage should be considered as a potentially important factor. A clinical trial to examine the importance of IFN inmmunomodulatory effects should include use of lower IFN doses and would likely be most meaningful in patients with minimal tumor burdens. In such patients, immunomodulation may be of greatest potential efficacy.

\section{Acknowledgments}

We wish to thank Dr. Paul Rosenbaum and Dr. Richard Raubertas for statistical support in the design of the latin square closing sequence and preparation of the exponential curve fitting program used in the analysis of cytotoxicity assays, and Ms. Karen Blomstrom for expert technical assistance in the preparation of this manuscript.

This work was supported by National Institutes of Health/National Cancer Institute contracts CM-07434-22 and CA-14520-11. Dr. Merritt was supported in part by National Institutes of Health/National Cancer Institute training grant T32-CA-09075.

\section{References}

1. Herberman, R. B., and J. R. Ortaldo. 1981. Natural killer cells: their role in defenses against disease. Science (Wash. DC). 214:24-30.

2. Roder, J. C., and H. F. Pross. 1982. The biology of the human natural killer cell. J. Clin. Immunol. 2:249-263.

3. Abruzzo, L. V., and D. A. Rowley. 1983. Homeostasis of the antibody response: immunoregulation by NK cells. Science (Wash. DC). 222:581-585.

4. Brieva, J. A., S. Targan, and R. H. Stevens. 1984. NK and T cell subsets regulate antibody production by human in vivo antigeninduced lymphoblastoid B cells. J. Immunol. 132:611-615.

5. Einhorn, S., H. Blomgren, and H. Strander. 1980. Interferon and spontaneous cytotoxicity in man. $\mathrm{V}$. Enhancement of spontaneous cytotoxicity in patients receiving human leukocyte interferon. Int. J. Cancer. 26:419-428.

6. Huddleston, J. R., T. C. Merigan, and M. B. A. Oldstone. 1979. Induction and kinetics of natural killer cells in humans following interferon therapy. Nature (Lond.). 282:417-419.

7. Pape, G. R., M. R. Hadam, J. Eisenburg, and G. Reithmüller. 1981. Kinetics of natural cytotoxicity in patients treated with human fibroblast interferon. Cancer Immunol. Immunother. 11:1-6.

8. Borden, E. C., J. F. Holland, T. Dao, J. U. Gutterman, L. Weiner, Y.-C. Chang, and J. Patel. 1982. Leukocyte-derived interferon (alpha) in human breast carcinoma. The American Cancer Society Phase II trial. Ann. Intern. Med. 97:1-6.

9. Lotzova, E., C. A. Savary, J. U. Gutterman, and E. M. Hersh. 1982. Modulation of natural killer cell-mediated cytotoxicity by partially purified and cloned interferon- $\alpha$. Cancer Res. 42:2480-2488.

10. Lucero, M. A., H. Magdelenat, W. H. Fridman, P. Pouillart, C. Billardon, A. Billiau, K. Cantell, and E. Falcoff. 1982. Comparison of effects of leukocyte and fibroblast interferon on immunological parameters in cancer patients. Eur. J. Cancer Clin. Oncol. 18:243251.
11. Edwards, B. S., M. J. Hawkins, and E. C. Borden. 1983. Correlation between in vitro and systemic effects of native and recombinant interferons-alpha upon human NK cell cytotoxicity. J. Biol. Resp. Modifiers. 2:409-417.

12. Maluish, A. E., J. R. Ortaldo, J. C. Conlon, S. A. Sherwin, R. Leavitt, D. M. Strong, P. Weirnik, R. K. Oldham, and R. B. Herberman. 1983. Depression of natural killer cytotoxicity after in vivo administration of recombinant leukocyte interferon. J. Immunol. 131:503-507.

13. Kariniemi, A.-L., T. Timonen, and M. Kousa. 1980. Effect of leukocyte interferon on natural killer cells in healthy volunteers. Scand. J. Immunol. 12:371-374.

14. Pross, H. F., and M. G. Baines. 1982. Studies of human natural killer cells. I. In vivo parameters affecting normal cytotoxic function. Int. J. Cancer. 29:383-390.

15. Fantes, K. H., and G. Allen. 1981. Specific activity of pure human interferons and a non-biological method for estimating the purity of highly purified interferon preparations. J. Interferon Res. 1: 465-472.

16. Cochran, W. G., and G. M. Cox. 1966. Completely randomized, block, and latin square designs. In Experimental Designs. John Wiley \& Sons, Inc., New York. Second ed. 117-147.

17. Perussia, B., V. Fanning, and G. Trinchieri. 1983. A human NK and $K$ cell subset shares with cytotoxic $T$ cells expression of the antigen recognized by antibody OKT8. J. Immunol. 131:223-231.

18. Perussia, B., S. Starr, S. Abraham, V. Fanning, and G. Trinchieri. 1983. Human natural killer cells analyzed by B73.1, a monoclonal antibody blocking Fc receptor functions. I. Characterization of the lymphocyte subset reactive with B73.1. J. Immunol. 130:21332141.

19. Hayflick, L. 1973. Screening tissue cultures for mycoplasma infections. In Tissue Culture-Methods and Applications. P. F. Kruse and M. K. Patterson, editors. Academic Press, New York. 722-728.

20. Edwards, B. S., J. A. Merritt, P. A. Jelen, and E. C. Borden. 1984. Effects of diethyldithiocarbomate, an inhibitor of interferon antiviral activity, upon human natural killer cells. J. Immunol. 132: 2868-2875.

21. Pross, H. F., M. G. Baines, P. Rubin, P. Shragge, and M. S. Patterson. 1981. Spontaneous human lymphocyte-mediated cytotoxicity against tumor target cells. IX. The quantitation of natural killer cell activity. J. Clin. Immunol. 1:51-62.

22. Callewaert, D. M., S. P. Smeekens, and N. H. Mahle. 1982. Improved quantification of cellular cytotoxicity reactions: determination of kinetic parameters for natural cytotoxicity by distribution-free procedure. J. Immunol. Methods. 49:25-37.

23. Edwards, B. S., M. J. Hawkins, and E. C. Borden. 1984. Comparative in vivo and in vitro activation of human natural killer cells by two recombinant interferons alpha differing in antiviral activity. Cancer Res. 44:3135-3139.

24. Alexander, F. L., J. A. Titus, and D. M. Segal. 1978. Quantitation of Fc receptors and surface immunoglobulin is affected by cell isolation procedures using plasmagel and ficoll-hypaque. J. Immunol. Methods. 22:263-272.

25. Sulica, A., M. Gherman, C. Galatiuc, M. Manciulea, and R. B. Herberman. 1982. Inhibition of human natural killer cell activity by cytophilic immunoglobulin G. J. Immunol. 128:1031-1036.

26. Sherwin, S. A., D. Mayer, J. J. Ochs, P. G. Abrams, J. A. Knost, K. A. Foon, S. Fein, and R. K. Oldham. 1983. Recombinant leukocyte $A$ interferon in advanced breast cancer. Results of a phase II efficacy trial. Ann. Intern. Med. 98:598-602. 